\title{
Right to Intimacy as an Expression of Feminism in the Works of Writer Manju Kapur
}

\author{
Dr Archana Rathore
}

Associate Professor, Department of English, DAK College, Moradabad, UP, India

This paper analyses the right to intimacy and love in the novels of Indian writer Manju Kapur, considering it as a strong dimension of Feminism. Being bold and audacious enough to break the barriers of orthodox prudery, Manju Kapur gives voice to the hitherto subdued feminism in Indian English fiction.

The twenty first century fiction firmament has seen the rise of certain brilliant stalwarts like Khaled Husseini and Paulo Coelho but when it comes to Indian writing in English, we find Jhumpa Lahiri, Kiran Desai and Manju Kapur, making a distinct place for themselves. But my focus is on Manju Kapur as she resides in India and especially because she has graduated with more poise and panache in the cosy canopy of intimacy in her last three novels. It is a psychologically proved fact that Intimacy is beneficial for individual health and well being. Individuals who perceive their spouses to be supportive confidantes are buffered from the pathogenic effects of stress. In contrast, people whose intimacy needs are not met feel lonelier (Rubenstein and Shaver 1982) and their relationships are more prone to dissolution (Hendrick 1981). Its course can be seen working in the marital journey of Astha and Hemant, Nina and Ananda, Virmati and Professor Harish and the families of Sona and Rupa. We have to look at intimacy from the marital point of view because of the socio-cultural context of India where Manju Kapur writes. "Even marriage, in the true religious sense of Holy Matrimony, does not depend on a romantic attraction to hold it together; instead it derives its meaning as an unbreakable act of family and societal service between a man and a woman to a mutual divine love."3 But then peeping deep into the philosophy of intimacy and especially the politics of marital intimacy, we fathom how difficult it gets to achieve that much-idealised and over-hyped divine love as the stark individuality of both husband and wife starts coming to the fore. Hemant in A Married Woman is busier in his business of making TVs while Astha keeps pining for his attention. Similarly, Ananda in The Immigrant tries to camouflage his sexual impotency by being busy in his work, not realizing the fact that how much Astha missed Anand especially because he was his anchor in this country. Neena needed more of this intimacy as she left her career and her country for him. And no doubt things get aggravated when in a foreign country. She confesses, "I don't know what I want. At home it was much clearer. I feel so lost here.'

'Feeling lost is inevitable in a new place-and if you are a woman without a job, far away from your own friends and family, it must be doubly hard. I thought of you when I read this.' Here Lore flipped open her copy of Shulamith Firestone's, The Dialect of Sex, page 101, 'Every person in his first trip to a foreign country, where he knows neither the people nor the language, experiences childhood.'

These words are resonant of Ashima Ganguli of Jhumpa Lahiri's The Namesake: “

"For being a foreigner Ashima is beginning to realize, is a sort of lifelong pregnancy -- a perpetual wait, a constant burden, a continuous feeling out of sorts. It is an ongoing responsibility, a parenthesis in what had once been an ordinary life, only to discover that previous life has vanished, replaced by something more complicated and demanding. Like pregnancy, being a foreigner, Ashima believes, is something that elicits the same curiosity of from strangers, the same combination of pity and respect." Talking of marriage, Kapur says that marriage was a social institution she reminded herself. A certain amount of presence was necessary for its successful functioning. Emma Goldman writes in her article 'Marriage and Love' in "Feminism: The Essential Historical Writings", "Can there be anything more outrageous than the idea that a healthy, grown woman, full of life and passion, must deny nature's demand, must subdue her most intense craving, undermine her health and break her spirit. Must stunt her vision, abstain from the depth and glory of sex experience until a 'good' man comes along to take her unto himself as a wife? This is precisely what marriage means." We find 
the resonance of these words in the female protagonists of Kapur's novels.

Manju Kapur has a non-commonplace gift for writing about commonplace people without exaggerating their dullness for effect or falling into dullness herself. "Deceptively simple" is an overused term from the critic's lexicon, but it sits very well on the works of Manju Kapur. Beneath the veneer of acute understanding of social hypocrisies, she is delving deep into the poetics of intimacy. So far, she has written four novels: Difficult Daughters, Home, A Married Woman, and The Immigrant. In all four, there are different dimensions of intimacy explored. In Difficult Daughters, it is clandestine physical encounters between Virmati and the already married professor, in Home, it is the mingling of man-woman bodies by virtue of being married and also there is this heinous sexual abuse of a young girl by his cousin, in A Married Woman, it is the lesbian relationship of Astha who "felt strange, making love to a woman took getting used to. And it also felt strange, making love to a friend instead of an adversary." In The Immigrant the lack of intimacy between Nina and Ananda creates havoc in their marital life. Here sexual inadequacy turns to insecurity, then infidelity and finally irreconcilability as Nina's inner feminist emerges.

Winning the Commonwealth Prize for the debut novel, Difficult Daughters explores the ebb and tides of a young student Virmati's life who succumbs to the infatuation of a much married Professor and this infatuation gradually turns into an obsession with professor's intelligent pleas winning against Virmati's reluctant inclination. After a number of vicissitudes, including a period as a school principal in a small Himalayan state, she finally marries the man she loves (or thinks she loves), and returns to Amritsar to live with him. However, he refuses to leave his first wife, and the consequences for Virmati are harsh indeed: she ends up being marginalised by her own family and despised by her husband's. Virmati's tale is told, from a present-day perspective, by Ida, her only daughter, who seeks to reconstruct her late mother's life-story, against the background of the Independence movement of the 1940s and the subsequent trauma of Partition.

Her second novel A Married Woman came in May 2004 and starts with its first line as ""Astha was brought up properly, as befits a woman, with large supplements of fear." But as the novel unfolds, we witness the changes in her life and gradually she breaks the taboos and leads life on her own terms, becoming a rebellion. Her American University educated husband Hemant is all she cares about as she thinks he is very liberal in thinking but somewhere down the line he succumbs to the stereotypical authoritarian role of an Indian husband. She pushes her frustrations aside and focuses on her duties as mother, wife and daughter. Her children, husband and increasingly -passionless marital sex take up her life. But the tensions continue to simmer, surfacing from time to time as paralyzing migraines. Then she meets Pipeelika, the striking widow of a political Street theatre actor. A rapport is quickly established between them, Pipeelika keeps his wife busy, he thinks smugly to himself, and she even seems to have fewer headaches nowadays. And besides, another woman couldn't possibly be a threat to his relationship.

Hemant couldn't be more wrong; against all odds, the relationship grows and the two women become intense lovers. But then she is caught between the terrible dilemmas as she feels guilty about her marital responsibility. She goes through a whirlwind of emotions as she's torn between her duties as a wife and mother and desires as a lover. Finally, Pipeelika leaves her to carry on her with her own life and she goes back ding her mundane life only decorated by her paintings.

She even desires to lead the day twice, once with Hemant and kids and once with Pipeelika. But then probably the writer herself couldn't muster up the courage to give this lesbian relationship a perfect culmination in Indian settings. Astha and Pipee have shared tender moments together during their love making; the relation is not allowed to travel the expected trajectory. The author making Pipee abruptly leave for the US to pursue her $\mathrm{Ph} \mathrm{D}$ is a narrative strategy which Patricia Juliana Smith calls 'lesbian panic'. Home is the third novel by Manju Kapur that came in 2006. This is the story of a large joint family of Delhi that has a flourishing business in the clothes trade. The household of Banwarilals have a fancy garments showroom - selling bridal clothes etc. - in the bazaar of Karol Bagh, Delhi's chief shopping destination for middle-class Indians. It starts off with the story of two sisters Sona and Rupa and treads very delicately on the margins of sibling rivalry, with a beautiful blend of sisterly intimacy and jealousy. But then the novel shifts to focus on Sona's daughter Nisha who as a young little girl becomes the target of sexual abuse by her cousin Gopal and has nightmares. Then she has her share of romantic bliss with Kabir but then again she has her share of heartbreak also as Kabir doesn't stand up to the confrontation by Nisha's family. Then the search for a 
suitable boy for her starts but just like Lata of Vikram Seth's A Suitable Boy, she ends up marrying the most unsuitable boy for her, or so it seems to me.

Kapur's latest novel is The Immigrant. It is about a 30 year old spinster Neena who is eventually married to Canada based Ananda, leaving her edifying career at Miranda House. Having a thunderstorm love affair with Rahul in her pre-marital life where physical passions ran wild, she confronts Ananda with his inability to keep her sexually satisfied. Her experiences in a foreign country are very much similar to Ashima's experiences in Boston. She is lonely and feels dejected to see her education and teaching experience go wasted. Then she joins a Library School where she meets Ashton with whom she feels at home and enjoys his love making too. But then one day he crosses his limits and imposes himself on her against her wishes. Thus her relation with him comes to an abrupt halt. In the meantime, she discovers about her husband's sleeping with a foreigner in her absence. After her mother's death and her defeat at both Ananda and Ashton's fronts, she decides to come back to her country, the place where she truly belonged to.

Studying these novels from the point of view of intimacy, the novel that comes out as a rebel against the socio-cultural norms seeped deep into the middle class sensibility is A Married Woman. Initially the husband who boasted that he wants to have a daughter and keeps on ranting against stereotypes of Indian husband, starts showing his true colours when she conceives the second time. And then starts developing an emotional lacuna that is filled by the love offered by Pipeelika. "From time to time she brooded about her own sexual nature, but her desire for Pipee was so linked to the particular person, that she failed to draw any general conclusions." The sociologist Jeffrey Weeks writes, "Social processes construct subjectivities not just as categories but at the level of individual desires." Although even in India also it is legal to have a homosexual relation but still it will take time for this community to get accepted in the society with respect. Recent theorists, such as Fred Klein, author of "The Bisexual Option" (1978), have expanded upon such commentary to validate bisexuality as a legitimate sexual orientation; one that Klein even argues is psychologically healthier than others because it gives freest reign to innate desires for intimacy.

Paula Rodriguez Rust, one of the foremost researchers on bisexuality, argues that the process of coming out is shaped by multiple dimensions, including not only sexual attraction and behaviour, but also political commitments, emotional ties, and community involvement. This is what is true of Astha's involvement with Pipeelika. Astha is not a woman whose sexual desire is focused on another woman. Astha's bonding with Pipee is not a choice exercised by a woman who would take the initiative to start and sustain a lesbian relationship. It could be interpreted in a certain sense, as an act stemming from resentment of her particular situation: "When she was with Hemant she felt like a woman of straw, her inner life dead, with a man who noted nothing." while with Pipee she felt like a woman and enjoyed the sexuality with her. "They had been skin on skin, mind on mind with nothing in between" and (Pipee) closed her hands over me, and I could scarcely breathe with pleasure," effuses Astha. This meandering into the arch of bisexuality is, thus, a refuge taken by As tha into the cosy canopy of Pipeelika, out of the dry and sublunary marital tie with Hemant. " In between they talked, the talk of discovery and attraction, of the history of a three month relationship, the teasing and pleasure of an intimacy that was complete and absolute, expressed through minds as much as bodies." And in the next page comes a substantial defiance, "Hemant should be pleased," said Astha to her lover, "he says women are always mind-fucking." They both laughed at wife's revenge."

After she makes love with Pipee the first time, she initially succumbs to panic realising that she is a wife too but then she argues "... not much of her was required there. A willing body at night, a willing pair of hands and feet in the day and an obedient mouth were the necessary prerequisites of Hemant's wife."

Its parallel can be seen in Deepa Mehta's movie "Fire" where the two sisters - in- law Radha and Sita are drawn into a sexual relationship as both are utterly neglected by their husbands.

In his 1973 book "The Colours of Love", John Lee compared styles of love to the colour wheel. Just as there are three primary colours Lee suggested that there are three primary styles of love. These three styles of love are 1) Eros, 2) Ludos, and 3) Storge. Continuing the colour wheel analogy Lee proposed that just as the primary colours can be combined to create. Three primary styles are:

Eros, meaning loving the ideal person, Ludos, meaning Love as a game and Storge, meaning Love as friendship. Three secondary styles are

Mania (Eros + Ludos $)=$ obsessive love

Pragma (Ludos + Storge $)=$ Realistic and practical love Agape $($ Eros + Storge $)=$ Selfless love . 
Reviewing Manju Kapur's characters through this "colours of love" lens, we can categorise love of Pipeelika as Mania and love of Veermati as Agape as she renounced her academic career as well as an enlightened life just because of her devotion towards the love of her life Harish, no matter how hard she suffers.

"For the first and only time, she has her own place to live, Virginia Woolf's famous 'room of one's own'; and yet she falls. She believes she needs a man, and she makes the wrong choice, returning to a relationship that had already brought her nothing but suffering. The repeated clandestine visits of the fatal professor lose Virmati her employer's confidence and she is obliged to quit her school, house and employment. ("Women on the Margins: Reflections on Manju Kapur's “Difficult Daughters"-Christopher Rollason, Jan 2004)

According to psychologist Elaine Hatfield and her colleagues, there are two basic types of love: compassionate love and passionate love. Compassionate love is characterized by mutual respect, attachment, affection, and trust. Compassionate love usually develops out of feelings of mutual understanding and shared respect for each other. Passionate love is characterized by intense emotions, sexual attraction, anxiety, and affection. When these intense emotions are reciprocated, people feel elated and fulfilled. Unreciprocated love leads to feelings of despondence and despair. Hatfield suggests that passionate love is transitory, usually lasting between 6 and 30 months. According to Hatfield, passionate love arises when cultural expectations encourage falling in love, when the person meets your preconceived ideas of an ideal lover, and when experience heightened physiological arousal in the presence of the other person. Manju Kapur's novels are replete with various instances of passionate love where the protagonists are instantly drawn to their lovers. And these wild passions barely held in check and the uncertainty of surging passions are so overarching that they keep reverberating in their hearts even after they are married. Probably this comparison arises because of the insatiability of their intimate encounters with their marital counterparts. Astha recalls the clandestine smooches of Rohan while on her honeymoon with Hemant and even finds her maiden marital lovemaking with Hemant a complete letdown. "Later in the privacy of the bathroom, Astha allowed herself to wonder whether she had been misled about the magnitude of the act." and instantly think about Rohan who had abandoned her in a cavalier manner and didn't show any kind of mutual respect and trust that are associated with compassionate love. But there are certain times when some thoughts are inevitable. "Unbidden thoughts of Rohan came. How slow his kisses had been, how infinitely long, how thorough.". Similarly Neena also thinks about Rahul, her exflame, just after her bridal night coital routine with her husband Ananda. "Involuntarily comparisons arose. Rahul, with his obsessive talk of sex, endlessly curious about what she felt in what position, this technique versus that." "Virginal or not, what she had felt with Rahul was alive."while Rahul was introduced in the novel as a serial lover and he moved on non-chalantly after his blandishments.

Even Virmati of Difficult Daughters also succumbs to professor's pleas every time they are making love while being an educated girl she should have moved on choosing a rightful place for herself in the society. "How does she know of the difficulties I face at home? How do you know of them, Viru? I come to you as a heaven. Except for this, my life is hell! Tantrums, sulks, sly accusations. My mother, my sister, daughter, all she has turned against me. And now you are doing the same thing.' He turned away and dropped his head in his hands. Virmati felt trapped. What had she been saying, was it so unreasonable? How could she leave him like this? Slowly she moved towards Harish, and slowly she took him in her arms." I would like to keep professor's love also in the category of passionate love. He is always springing out the tentacles of his syrupy cobweb of intimate billet doux language. Every time Virmati tries to gather herself together and be resilient in her inclination towards the Professor, he comes with more skill and beauty in his letters. And this cloying sweetness is perceptible to everybody other than the wide-eyed blindness exercised by Virmati.

Nisha, the daughter of Rupa in Home also falls in love with Kabir and gets completely bowled over by him. Their affair is given ample space and Nisha feels so strongly about their relationship that she is ready to take cudgels against the whole of the world. But then Kabir leaves her in the lurch after having a good time with her.

From the standpoint of intimacy, there is a remarkable increase in the exploration and explicitness of physical teteà-tête between the counterparts in Kapur's last novels than the first. And also noticeable are the demanding libido of the wives and consequently, the desperate endeavours of the husbands to keep their organs and self esteem erect. In A Married Woman, we have Hemant who immersed himself in sex manuals with graphic illustrations and in The Immigrant, we have Ananda who initially sprayed anesthetic on his penis to delay the climax and then went on 
to undergo the couple sex therapy to improve this important front of his. Manju Kapur is comfortable flaunting off the intimate desires of both Astha and Neena.

"Astha had not imagined that sex could be such a master. Slightly ashamed, she kept hidden that she longed to dissolve herself in him, longed to be the sips of water he drank, longed to be the morsels of food he swallowed. The times he was away she was focused on one thing, the moment of their union. When he came through the door, she wanted to jump on him, tear his clothes off, thrust her nipples into his mouth, and have him charge his way through her. One with him, one with all that mattered.

I haven't really lived, thought Astha, till now I did not know what life was all about.

She felt a woman of the world, the world that was covered with the film of her desire, and the fluids of their sex."

She even starts having a relationship with a woman Pipeelika. In this relation also she reveled into her own delirium of thoughts with her lover.

"Astha was in love. All day she thought of her, visualizing the turn of her neck, long, sloping, unornamented, the collar bones on either side of the small hollow the base of her throat, the screws of her hair latticed, as she had once seen them against the dark, heavy, green of the trees of the Tagore Arts Centre.

Meanwhile her best time at home was when she fantasizing about the one she loved without interruptions, lost in her thoughts, wallowing in her feelings."

If A Married Woman is daunting enough to showcase lesbian ventures of Astha, The Immigrant is pretty unabashed about self gratification by Neena, again because of her husband's inability to quench her sexual thirst.

"She wondered whether she needed to be more emphatic, but the state of permanent sexual frustration she was in made it difficult. It grieved her that Ananda had no notion of how she felt. Her idea of matrimony was a husband who was a little more alert to the discreet clues she let drop. Long moments were spent gazing at herself in the mirror, in her underwear or sexy nightie. In the soft glow of the pink tiled bathroom, she looked dazzling. Her bare skin, the curves of her body, her black hair falling over her shoulders, all were delectable. Desire rose in her as she communed with her reflection. She pushed her breasts up, and gazed at the seductive cleavage that would surely drive any man to fondle. Having a husband should not have meant such lonely desperation."

Another thing that is very pertinent in Kapur's novels is the room given to another very interesting and inevitable dimension of intimacy and that is infidelity in the matrimonial relationships of the protagonists. Difficult Daughters has the already married Professor vying for the much younger student Virmati, HOME, A Married Woman has Astha straying into a lesbian relationship with Pipeelika and there is a passing mention of a condom found in her husband's suitcase, implying his sexual vagaries. The Immigrant has both the husband and wife getting their sexual cravings fulfilled with foreign counterparts. Explanations for sexual infidelity have been dominated by an evolutionary psychological theory of jealousy that finds its strongest support in research that employs a forcedchoice hypothetical infidelity paradigm wherein participants imagine experiencing infidelity and choose whether sexual or emotional infidelity would be more distressing. As Astha comes to terms with this when she sees a condom in Hemant's suitcase or Nina catches a yellow hair on her marital bed that was used by Ananda with somebody in her absence.

Elaine Hatfield and G William Walster quote A. Ellis's maintaining the fact that adultery may be beneficial, in their book "A New Look at Love".32 Ellis maintains that though there are dangerous repercussions of extra marital affairs but he points out at least three reasons why it is beneficial. Frustration Reduction- Many individuals find monogamous mating limiting and frustrating, particularly when their mates do not have sexual appetites similar to their own. (Neena is one such wife who had to reciprocate the sexual insinuations of her Library School class mate who was involved with her purely on physical basis as her husband Ananda was inadequate in sustaining his erection for long.) Improved Marriages - Either or both married partners may feel less sexually and generally frustrated after an extramarital affair and thus less resentful towards each other...They may be more open and honest with each other. Sex relations may be improved along with greater appreciation of the partner. (Here again we can quote Ananda's case as he gets involved with a foreigner Mandy. See the irony in the words:

"His wife was so trusting, so easy to deceive that his love for her increased exponentially. 'Any time you want my help just let me know,' he frequently said, as he watched her painstakingly go through Library School prospectus, tick possible courses, and double check her choices with Berth on the phone."

Improved sex in marriage- Just as humans learn about sex in their premarital affairs, they will tend to learn about their own and others' sex proclivities in their extra marital 
relations...This is especially true if the individual's premarital affairs had severe limitations. Earlier sexual knowledge can be used to bring a more efficient and more enjoyable degree of sex to marriage.

It is very perceptible in the case of Ananda who undergoes a sex therapy also and later on gets involved with Mandy. But then Ananda gets obsessed about his sexual performance and this in turn, irritates Neena. "When it came to counting his thrusts inside her, she rebelled. Ananda, it is about love, it's not only about performance."

The last thread that caught my fascination reading Kapur's works is an interesting similarity amongst all her heroines. Virmati, Astha, Nisha, and Neena: all are students of English Literature. Does being associated with literature, bring certain sensibilities that make a person more inclined towards intimate passions? Or just being women mean allocating higher rung on the ladder of priorities? More often than not, it is men who are erratic lovers while women are steadier at love. But what is it about these men that fascinate women so? What is it about a wayward love that is so fascinating for Manju Kapur heroines? Why do they repeatedly forgive and accept back into their lives and hearts men whose constant infidelities torment them?

I guess it is the elusive charm and fascination of unfulfilled love; infinite passion and the pain of finite hearts that yearn for more and more...More love and more pain.

\section{REFERENCES}

[1] Difficult Daughters. New Delhi: Penguin India, 1998; London: Faber and Faber, 1998.

[2] A Married Woman. New Delhi: India Ink, 2002; London: Faber and Faber, 2003.

[3] Home. New Delhi: Random House India, 2006; London: Faber and Faber, 2006.

[4] Lahiri, Jhumpa. The Namesake. Mariner Books Rollason, Christopher, Women on the Margins: Reflections on Manju Kapur's 'Difficult Daughters' January 2004

[5] Rubenstein, C., \& Shaver, P. R. (1982). In Search of Intimacy. New York: Delacorte. Dutch and Belgian editions, 1984: Eenzaamheid: Hoe onstaat het \& wat doe je eraan. Baarn, The Netherlands: De Kern; Deurne, Belgium: Baart.

[6] Hendrick, S. S. (1981). "Self-Disclosure and Marital Satisfaction." Journal of Personality and Social Psychology 40:980-988

[7] Klein, Fred. The Bisexual Option. New York: Arbor House, 1978.

[8] Rust Paula C. Rodriguez (Editor), Bisexuality in the United States: A Social Science Reader, November, 1999

[9] Lee, J. A. (1973). The Colors of Love. Don Mills, Ontario: New Press
[10] Hatfield, Elaine, \& G. William Walster. A New Look at Love. Reading, MA: Addison-Wesley, 1978; Lanham: University Press of America, 1985. Love \& Mate Selection.

[11] Mehta, Deepa Fire (movie) 1996 